\title{
CHALLENGES FACING PUBLICITY AND MARKETING OF NIGERIA COMMERCIAL THEATRE IN A DEPRESSED ECONOMY
}

\author{
Hannah Modupe Akpodiete (Ph.D.) $)^{1 *}$ \\ ${ }^{*}$ Lecturer, Department of Theatre Arts, Delta State Un 1iversity, Abraka, Nigeria. \\ Phone+2348023176907 Email: dupedudu2018@gmail.com
}

*Corresponding Author: -

Email: dupedudu2018@gmail.com

\begin{abstract}
: -
For a commercial theatre to remain in business, it must continually adjust itself economically, socially and politically to its immediate environment. The world is changing so fast that industrialised economist has equally changed drastically. This has necessitated the increase in global competition and liberalisation of markets combined with change in consumer demand, values and priorities. This has forced companies to cut out wasteful and unproductive activities and concentrate on areas of competence to achieve sustainable competitive advantage. Also, the worldwide economic recession has reduced the consumer purchasing power and brought companies face to face with complex cross-cultural issues and competition that necessitates aggressive publicity and marketing for its survival in a depressed economy. Furthermore, to survive this unprecedented turmoil, most organisations especially commercial theatre had to embark on a number of measures including aggressive publicity and marketing, For the theatre industries to survive the 21st century in a depressed economy, it must be responsive to its environment, as well as be creative, built on trust and developed selfknowledge. To achieve this the qualitative research methodology was employed using the Laissez faire Model of economic recovery in recession. The marketing/publicity manager could help the Commercial theatre achieve her corporate vision through allowing the spirit of cooperation and teamwork among all partners within the organization. This paper therefore analyses different methods used by commercial theatre organisations in the current dispensation when the nation is facing a downturn economy and equally suggests new strategies employed by them towards alleviating their economic challenges
\end{abstract}

\section{(c) $(\$)$}




\section{INTRODUCTION}

Effective management is the soul of any business venture or organisation. In the business world it is acknowledged that the success or failure of any business depends on how functional its management department is. So, every business organisation holds in high esteem its management arm as much as its production outfit.

The Nigerian theatre as a profession is no exception in the misdirection of values. The acceptance of management as an art that must be carefully learned, and practiced to enhance creative activities is not pronounced among theatre scholars, When a production does not break even, the blame goes to the management arm of the organisation but in a situation of successful production, the actors as well as the director are praised. Management is denied the attention it deserves because of this misconception and the directors jack of all trade attitude, which usually results into quarrels between management and artistic director it has been difficult for theatre managers to convince Board of Directors who frequently expect quick results that theatre audiences are built up within years of patient slogging and not overnight. So, most directors employ mediocre or volunteers without artistic orientation, lack of administrative background and artistic sensitivity which is necessary for effective art administration.

The Nigerian theatre has not grown to maturity or state of independence because of misplaced priority that has infiltrated our theatres. The only way to correct this anomaly is to give management its rightful place in the theatre organisation. Well sophisticated managers who appreciate artists and their constraints, with a professional background should be employed and given well spelt-out duties, autonomous hands to operate so as to enhance their creative interpretation of the company's policies. Managers' ability to tolerate others, understand the motives of others, have a goal, plan, is essential for effective interaction with workers and a conducive atmosphere which will enhance management efficiency.

\section{The concept of commercial theatre}

Theatre in its widest sense is an art. Its ephemeral nature makes its effect powerful on the audience. Its complexity and combination of several artists for its creation has made theatre to be defined as getting things done with and through the effort of other people.

There are different forms of theatre such as community theatre, educational theatre, commercial theatre, children's theatre, professional theatre, and amateur's theatre. The purposes and objectives of each depend on the type of theatre. This differentiate one theatre from another. Despite this, the primary aims and values of the theatre, not minding the form, transcend all types of theatre activities. Theatre as an art is as old as man. It is the meeting place for other arts and a vital source of aesthetic pleasure. It provides man with exciting, stimulating, emotional and aesthetic experiences. By conceiving an idea, work on by a dramatist, inviting an audience to watch thereby appealing to their emotion and pleasure to get their reaction, which can be positive or negative to achieve the main aim of the production which can be to entertain, educate, make profit or for healing. When these elements are put together art can be seen according to [John E. Clifford; 1992, P.3-4]

...... as the process in which an artist, after experiencing inspiration, attempt

to share that experience with others by creating an object which, when experienced by others, will provoke a pleasurable and emotional experience similar to the original inspiration.

Theatre does not only reflect on nature but also on human behaviour which facilitates its invention of revolutionary philosophies. It also enhances its contributions to man's intellectual, social, moral and recreational needs. So, the major purpose of theatre activities is exclusively the satisfaction of man's diverse needs.

A commercial theatre is a theatre organisation or theatrical production that is embarked upon with the primary aim of making gain, it is organised and run purely as a business venture. This type of theatre is run professionally on full-time basis, with staffers and cast paid on monthly basis. Apart from the major aim of the commercial theatre, which is to make gain, it also entertains, preserves the cultural heritage of the people, increases the people's taste for standards and quality theatrical entertainment. To enhance the achievement of its major aim, it also encourages artistic excellence in the art of the theatre, and competition among theatre companies.

\section{The Origin of Commercial Theatre \\ The Inception of Trade}

The earliest trade started thousands of years ago before Christ. Primitive trade in Europe were dated as far back as 2500BC. From 1700 BC trade took a new turn, as the Cretans traded extensively by the sea. As early as 300 BC the Egyptians, in search of gold, antimony and slaves have sailed down the African coast as far as the Zambezi river, nearly 5,000 miles away from the sea, while the Phoenicians were operating from a narrow coastal strip in the far Eastern Mediterranean. They built urban centres in Sidon and Tyre as their focal points for land and sea trade. They had good navigators and a broad knowledge of sea routes and wind. These knowledges were carefully guarded from potential competitors. They traded in wide variety of goods from Spain, Egypt, Central Africa, Syria and Arabia. The Phoenician established famous trading centres around the Mediterranean and even the Atlantic Coast, keep careful records and used the oldest known bills of exchange and mortgages. This trade was characterised with great risk- both natural risk such as storms and human risks such as piracy and brigandage-and was hampered by poor transportation.

These limited the trade to easily transportable, high-value products. By the late Roman era, almost all the Eastern hemisphere were linked by trade. The incursions of Northern tribes into Roman empire in the 5th century and the spread of Islam across the East and North Africa in the 5Ath century disrupted trade in the Mediterranean area. Trade became insecure, a subject of extortion by local chiefs and feudal lords as a means of enriching themselves. Trade activities became disrupted and traders were seen as suspect. 
Organised trade in Europe languished. But it flourished especially between the Arabs world and India. The discovery of new route in the Far East and New world, in 17th. century revolutionised both the geographical pattern and the commodity composition of foreign trade. Several practices essential for modern day trade were introduced. They included conventions regarding commercial contracts, risksharing through commercial insurance and the introduction of paper far cheaper than parchment on which business records were kept.

These development in trade gave a fillip to commercialisation. Industries were also greatly stimulated. It induced the formation of many partnerships and joint stock companies, to raise large sums to launch a voyage and establish trading centres abroad [The Encyclopedia Americana 1974, P . 913]

Also, the system of mercantilism was imposed on foreign trade to enrich the home country, both in gold and silver and employment in manufacturing companies. Despite these, the bulk of foreign trade continued to be in basic raw materials and foodstuffs up to the 20th century.

In the 20th trade in iron products and textiles grew rapidly but there was little in machinery. The improvement in technology fostered greatly during this period. Transportation within countries also improved because of better roads, canals and security. These facilitate the rapid growth witnessed by the commercialization of industries in different countries at different eras. It gave birth to the polarization of professions, which later resulted into the commercialisation of these professions [The Encyclopedia Americana. 1974, P. 914].

\section{The Origin of Commercial Theatre}

Commercial theatre has gone through many phases of development right from its inception in the ancient Greece. In the middle of the 5th century B.C. organisers of Dionysian dramatic activities were charging fees for performance with the intention to reduce the audience in the auditorium at the Acropolis.

The theatre then was run by the state. It was partly sponsored by the state and the choragi, under the supervision of the Archon. Tickets were introduced for the first time in the theatre to curtail the audience's attendance in the theatre. Secularisation of the theatre started in the ancient Rome in the fourth century. State appointed impressarions, allocated budget to him to produce spectacular activities whereby they charge fees and make profit. [Oscar G. Brockett: 1968, PP.108-109]. Brockett gave the figures of some of the performances in some towns that were successful.

In 1.490 in Reims, 5616 persons paid fees to watch performance, at Romans in 15094780 attended performance.

Even though, most performances were free, paid performances still strived. The modern commercial theatre started in England around the 16th century alongside professionalism in the theatre.

During the reign of Queen Elizabeth, actors that have been regarded as rogues and vagabonds were given recognition by the government. This was the first step to the emergence of commercial theatre in England. [Oscar G. Brockett: 1974, P.460]. With these new developments all the troupes that have been operating secretly started operating openly after obtaining licenses. In 1574 'the responsibility of issuing licenses was transferred to the Master of Revels-a court official who also censored all plays. Troupes can only be granted license after being under the patronage of a nobleman whose name would be used to receive the license from the central Government. So many companies employed this opportunity but the most prominent were the Lord Admirals' men and the Lord Chamber Iain's men. The Lord Admiral's men were founded by the Lord Hawood around 1576. The founders were famous actors, and the troupes were known for quality performance. While the Lord Chamberlain's Men was founded by Lord Hunsdon in 1564, In 1585 the troupe's name was changed from the Lord Hunsdon's men which was its original name to Lord Chamberlain's men. They were the most popular troupe, which was made possible because of the genius playwrights and actxirs in the troupe such as Shakespeare, Ben Johnson, Beaumount and fletcher. [Oscar G. Brockett: 1986,P.193], Because of these immense achievements recorded by the Lord Chamberlains Men, In 1603 when king James came to the throne he took over the troupe and placed it under his direct patronage. The troupe's name was changed to the king's Men. He encourages individuals to contribute to the development of commercial theatre in England.

\section{Origin of Commercial Theatre in Nigeria}

All the nationalities that made-up the contemporary Nigeria had thriving traditions of literature before they met the European influence. Most of these traditions have declined because of the embracement of the western culture.

The itinerant theatre was started by late Hubert Ogunde in 1946, He started by using sacred church drama already popularised by A. Ajisafe, E. Dawodu and Ajibola Ayeni as native air opera popularly known as Alarinjo, a word which originated from an abuse meaning rogues, vagabonds and study beggars but widely known as "Alawada". This theatre originated from a society of masquerades around the middle of the sixteenth century [Yerni Ogunbiyi (ed.): 1988, P.4]. Though critics have argued that Late Ogunde's theatre cannot be - regarded as the first professional theatre, but he can be acknowledged to have started the first commercial theatre in. Nigeria. Ogunde's theatre company came in a new dimension with the professional actors performing without masks to the audience the first time in the history of Nigerian theatre. The theatre was retrieved from the traditional patronage of the court and religious organisations to depend solely on the patronage of the public. He introduced the use of ticket which is the box-office system and gate taking realised were used for the maintenance of the company instead of the sharing method of the Alarinjo theatre.

Ogunde introduced a lot of modern theatre facilities into the company, Such as the use of posters and advertising in Newspapers to publicised his productions. The use of a proscenium stage, modern theatre equipment such as lighting, sceneries and sound amplification. These really enhanced his productions, attracted audience and brought uniqueness to his productions. He was the first person in the history of Nigerian theatre to employ actresses as star artistes in their own rights. Recruitments were made through advertisements in the local newspaper's payment of salaries and realism and 
dialogue were introduced into the Yoruba theatre. He encourages and participated in the revival of cultural consciousness of the forties using Yoruba oral literature in his operas [Ebun Clark:198]

Late Ogunde was target as an achiever in the theatre business because of his ability to single-handedly give the Yoruba theatre a new "impetus and dimension" and establish the loosely termed contemporary Yoruba theatre of which remained the foremost exponent till death. The success recorded in this art was not come by overnight. It was as of a well-conceived ambition, practiced under the patronage of the church in 1943 before launching out in 1945. [Ebun Clark 1980, P.5].

These had immense influence on the theatre till date. Today, commercial theatre cannot be totally excluded from this influence because they employed some of Ogunde's method though the modern theatre practitioners improved on to facilitate their performances.

\section{Organisation}

A theatre tie to the profit-and loss type of economy can only be successful if financial reward is placed before the art itself. Between 1568 and 1642 in England, troupes were organised on a sharing basis. Actors who have become partly owners of the company buy shares from the company and share both the risks and profit of the company. [Biodun Jeyifo 1984, P.1]. A company is only allowed to perform after signing the Bond of Association which qualifies troupe to obtain patent or a warrant to perform. It was managed by the shareholders with each person responsible for a specific area such as costuming, playwriting, designing and acting. Non-shareholders were employed on a contract basis. There were four major classes of people that made up the troupes of this period. These include - the house keepers, the actor-sharers, the boy apprentices and hired men. The house keepers were the theatre owners they may sell their shares or bequest it to their family or anybody at death or retirement. The boy apprentices were those who impersonated women in performances; because women were not allowed in the theatre.

Between 1.584 and 1597 the acting profession had grown to a level of it sustaining actors. It had become a reliable occupation in which actors will invest a reasonable sum of money and was safety guaranteed. Before the imminent of theatre building, plays were performed in courts and inns. This can be classified under two types-the private theatre and the public theatre. The private theatre was exclusively for the aristocratic audience while the public served both the aristocratic and the populace. The public theatre was made up of three parts - the pit or yard was the lower-class audience stand, and the galleries with benches which seated the middle class alone and a box reserved for the nobles. These attracted different fees ranging from one penny for yard, two pence for gallery, and three pence for the box audience [Biodun Jeyifo: 1984, P.2].

Performances were advertised using posters and hand bills, processions with drums and trumpets were used hours before performances along major streets of the town. Flags were at times placed- at the roof of theatres. Attendance of private theatres was about five hundred while public theatres was three thousand. [Oscar G. Brockett; P.181]. This shows the importance of publicity as a vital tool in marketing even as far back as the ancient era. Though there were no box office, but gatherers - men and women who sold tickets for admission at the entrances of the theatre.

The Elizabethan period has been described by theatre historians as the most vigorous and spectacular period in the development of theatre in England. This can be seen from the versatile playwrights produced in this era. The building of permanent theatres as well as the evolution of theatre as business venture, as well as its proliferation most actors withdrew from being partners in their own theatre company.

Today commercial theatre is as common as any company in most countries of the world. The Broadway New York, America, the producer is in charge of the production, because he is in charge of the financing and sales, he contracts for the plays, secures a director, a theatre and sources for the necessary financial backing, Publicity and sales of tickets, and other necessary arrangement are his tasks to perform. The producer is the brain behind the success of any production. Though he is not directly involved in the artistic aspects of production, he has great influence on all the theatre workers. Play production in Broadway starts with the producer soliciting for scripts from playwrights or their agents. With the intention to choose a play that is profitably viable. After making his choice, he will purchase an option- which is a legal right to own and produce a play for a specific period. This must be agreed on during the negotiation between the dramatist and the agent. Because of the huge amount involved in production which runs from two hundred thousand dollars to one million dollars for simple and complex production respectively funds are sourced for.

To raise this huge sum, the producer forms a limited partnership company which can be divided into two. The general partnership, which is the producer alone and the limited partnership which is the backers who contribute the entire fund needed for the production. The backers earn $50 \%$ of the profit after production while the producer also collects the rest $50 \%$. To authenticate the business, the law requires that the. play prospectus with the partnership agreement amongst other relevant document be filled in the office of the Attorney of the state of New York, with the security and exchange commission present. The prospectus contains the synopsis of the play, short biographies of the author, producer and other artists who have committed themselves to the production. It states details of the financial and legal fate of the company as well as the risk of the investment.

Having granted the money, the producer steps out to draw his budget of the production from the opening night of the performance to the last night, Statement of how profits are to be shared are presented to investors who may accept it or demand for adjustment of the statement.

In the process of performance, he has to negotiate with at least eleven different Unions representing these groupsdirectors, actors, choreographers, musicians, stagehands, wardrobe attendants, press agents, managers, treasurers, ushers, doormen, playwrights, porters, cleaners and engineers; each has minimum charges which the producer must pay. The league of New York theatre requires that theatre press agents whose concern is to sell the production and responsible for all news releases and advertising of the production, must ensure that pictures of important scenes and actors are available 
to the press. The press agent puts in all he can afford to make the public interested in the Play. Publicity is promotion that is achieved at little or no cost to the promoter.

The company commences publicity and advertising of new plays at. least three weeks before the performance. The publicity manager is assisted by-two poster men who helped in posting the posters at strategic places, as well as advertising on television and radio. While the promotion Manager organises touring arrangement within the country and foreign countries. In the early days of the Moses Olaiya company, productions were publicised in Alawada publications and the Alawada Spot hotel which was located in Ibadan and also served as a centre where theatre fans went for information about new plays or to know when, where and type of productions.

Publicity was also carried out through Moses Olaiya's dressing. Being a comedian, he dressed in such a comic manner that, attract and amused audience and made them inquisitive about the performance and wanted to watch the performance, Moses Olaiya plays major character, parade most of the main street in the town with his costume before performance. After parading the city with these colourful and farcical costume the turnout of audience was always impressive. Though in those days most of the opportunities available to the theatre practitioners now were not available then. Still the founder's relationship with the press enhances the company's publicity of their product. And most of their productions were successful, in terms of gate takings. Despite these, publicity and advertising did not really fake paramount position in the company's budget, because of the theatre culture that has already existed in the country due to Ogunde's drama. People were already conscious of the theatre so the Moses Olaiya International Alawada Theatre group did not bother to carry out aggressive publicity/advertisement because they thought it was uncalled for.

In the later days of the company, before it finally closed up, it came to the realisation of the organisation that the only means of keeping the theatre audience is through affective publicity and advertising. This realisation was made evident because of the economic effect of the structural adjustment programme on the company, and the emergence of the home video industry which diverted the theatre audience, because of the aggressive publicity employed by the industry nstead of rising up to the challenges posed by the home video industry, the company folded up. The theatre troupe disbanded in 1936 while the attention of the company was shifted to film making.

The Alawada theatre now has an arm of its company which specialises in home video making, Moses Olaiya holds that, since his primary purpose of having established, the company was to entertain people he has achieved his mission to its fill and is still doing the same through home video film.

Fezi productions is based in Lagos, city characterised by highly competitive business hustle. The economic degeneration which the country is experiencing has adversely affected every industrial activity in the country. This has affected the financial status of individuals and companies alike. To maintain her objectives which are to raise the theatre to a total commercialised level and to put up artistically excellent production the company operate under three major department with the artistic director as the overall head.

\section{Ways Of Generating Additional Funds}

Revenue/ticket sales alone cannot be enough to sponsor theatre productions. Because of the huge amount involved in play productions the theatre today has to depend on other sources called contributory or subsidiary income which has been a major area of the total theatre budget of most theatres either commercial or nonprofit venture.

Fund raising is unlikely to succeed unless it is well planned. A lot of theatre practitioners have misused this opportunity. So, its successful realisation depends to a very large extent on the quality of the fund raising leadership board of trustees and volunteer supporters. Though many theatre practitioners has been frustrated and suffer loss of valuable time because they annually appeal for sponsorship While some agencies granted sponsorship appeals depending on the type of play, some arms of the government sponsor plays that have direct bearing/theme with their activities or that will educate the audience on certain vital issues. For instance, Second Chance was sponsored by sixteen different small companies, while Spunk was sponsored by the United State Information service [USIS] all because they were relevant to their activities as an organisation.

Before approaching any organisation for financial assistance, it is better to know as a matter of policy the type of projects the agency or organisation supports and what type it rejects. This will not only enhance the success of such fund raising, it will also influence the choice of play.

Most commercial theatres sell advert spaces in printed programmes. It should be improved upon programmes should be colourful, attractive and not wordy to enable it to contain more information. Ticket, envelopes, printed brochure, performance schedule booklet, lobby display space, the asbestos, curtain may be used as an advert space, which will earn additional money for the theatre,

Renting of theatre building to users or groups is a lucrative source of generating revenue that theatre practitioners should exploit to raise fund. For instance, Cinema De Babasala is rented out at the rate of eight thousand Naira per night. In theatre where productions are not daily, it should be rented out for social functions such meetings, film shows, musical shows and cultural activities. Apart from the education theatre - situated in institutions of learning which can boast of theatre buildings, only few commercial theatres can boast of theatre building. Even the Cinema De Baba Sala is own by the government and leased to him by the Oyo state property Management Board. To move the theatre to a greater height practitioner should give priority to theatre buildings. Rentals has been one of the major sources of generating revenue by the National theatre till date.

Despite the demanding, thankless and frustrating nature of the work of the theatre, the publicist is the link between the theatre and the general public who creates a lasting love affair between the theatre and the devoted audience. This cannot, be achieved with complacency but with hard work and making sure productions promote first the producing u. gani sat ion and secondly the overall success, the image and reputation of the organisation. This enables a large percentage of the 
audience to support all its productions. Audience should be encouraged to enjoy theatre-going in general not to watch well known plays and performances alone. To promote the producing organistion, the pub bbbbbbbbb m nblicist depends on the support of every members of the organisation - all kinds of support that, will make attendance of theatre enjoyable is determine by, how customers are treated by ticketing officers, ushers, house manager', doormen, parking attendants and how the theatre building is neatly maintained, pay bills and lobby display enhance the excitement of theater goers. The atmosphere, physical setting and the circumstances around which plays are produced usually make the difference between first timer and regular customers. A lot of sacrifices, commitment, dedication and effort goes into theatre promotion than a few adverts in local newspaper.

\section{Problems affecting Commercial Theatre companies in Nigeria}

The main objective of this aspect is to examine the problems facing commercial theatre in order to determine the extent of its economic viability.

Since finance is so crucial to the survival of the theatre company, there is an urgent need to explore all possible avenues - both private and public to supplement the gate taking which is always inadequate for the funding of the theatre. The major sources of funding for commercial theatres are income generated from box office, financial support from foreign bodies, corporations and individuals who are art lovers. And contributions from founding fathers and patrons. Because of this poor financial background most commercial theatres find it difficult to plan ahead. This is why most commercial theatre employ the use of their family members as staff and cost in the company to reduce cost. And for those who the employees on their part are initially admitted as amateurs who are required to undergo an apprenticeship training period in order to avoid paying them. The box office is very important to commercial theatres because it is their more certain and regular source of income. Every performance is presented with the intention of breaking even. But the extent to which this is achieved depends on the level of marketing and publicity employed by the company. Most theatre companies hardly have financial records of the company's financial status because of the use of novice as business managers. Which made it difficult to determine the exact percentage of boxoffice contribution to the theatre companies.

The Federal government hardly sponsors productions, and if she does theatre companies are so many that it may not go around once in two years. So, theatre companies rely on foreign private foundations and wealthy individuals who can sponsor productions. These bodies played important role in the sustenance of theatre in Nigeria. For instance, the production of Iphigeni meets Aiyelala was sponsored by Goethe institute a Germany body and Z mirage a lighting company in Nigeria. It is through such programmes and exchange programmes that the Nigeria commercial theatre finds an opportunity to exhibit their cultural worth to the international community. Though they earn money for themselves but most importantly they are exposed to modern theatre technologies which are useful to the growth of modern commercial theatre. Though the support of this foreign bodies and institutions to the theatre has been on the decline but they are worth mentioning because they have constituted a regular source of funding for theatre companies in Nigeria. Their assistance to the development and sustaining of the theatre in Nigeria is caused not only by their love for African Arts and culture, but for the desire to promote cordial diplomatic relations between their home countries and Nigeria. With the advent of home video, wealthy individuals in the country are now realising the importance of investing in productions and films more than before.

Due to theatre companies' financial inconsistence, which mostly affected their productions in terms of not using the right costume, props, even lighting equipment which led to their not having an annual drawn budget and those who have do not abide by it. The budget of a profit-oriented theatre company as in the case of a commercial theatre, is determined by some very important factors that must be taken into consideration before such an estimate is drawn. These factors include the source of income and the estimate of revenue that will be generated from each source. The number of performances expected to take place, and the audience expected. It is important that the income must be higher than the expenditure. The general mood of market and the economic status of the country will be a general determinant of company's optimistic projection.

The economic depression which crept into the country as a result of the global oil glut, led to serious austerity measure, coupled with high inflation, reduced the wages of worker in all sectors, thereby reducing the amount that could be allocated by individuals to entertainment, like watching film or life performances. This has caused a rapid decline in the theatre audience as a result of economic hardship experienced by citizens.

The advent of video cassette and local film has caused the drifting of theatre audience coupled with poor financial in capabilities. They prefer to stay in doors to watch television or home video cassettes.

Another major factor that led to the decline of gate taking which was caused by decline in audience attendance is the presentation of plays that are not relevant to our society. Because of the influence of the western world most theatre companies presented plays of imported moral value that are of no importance or meaning to our cultural, aesthetic and traditional values. Most of these plays preach violence and vices, they in no way contribute to the social cultural or political development of the audience. Since the audience does not derive satisfaction from such performances, they are not encouraged to attend Productions. Main criticisms against advertising are: increased price of the product, multiplication of needs, deceptive, it leads to monopoly, harmful for the society, wastage of precious national resources. Despite many benefits drawn from advertising, it suffers from a severe criticism advanced by different segments of society.

It is not an unmixed blessing. It has been criticised on the following grounds. 


\section{(1) Increased Price of The Product:}

Advertising increases the cost of the product as the expenses on it form the part of the total cost of the product. The increased prices are borne by the consumers. But it cannot be denied that advertising leads to large scale production which considerably reduces the total and per unit cost of production. The consumer may pay less rather than higher.

\section{(2) Multiplication of Needs:}

Advertising creates artificial demand for the product and induces people to buy those products which are not needed by them. On account of its repetition, it allures and creates a desire in the minds of the people to possess an article not required by them.

\section{(3) Deceptive:}

Sometimes advertising is used as an instrument of cheating. In order to impress upon the people false statements are given with regard to different virtues of a product. Fraudulent means and deceptive practice are resorted to by various traders in order to sell their products. All these things adversely affect the public confidence in the advertising.

\section{(5) Harmful for the Society:}

Sometimes advertisements are un-ethical and objectionable. Most often, these carry indecent language and virtually nude photographs in order to attract the customers. This adversely affects the social values.

\section{(6) Wastage of Precious National Resources:}

A serious drawback levied against the advertisement is that it destroys the utility of certain products before their normal life. The latest and improved model of a product leads to the elimination of old ones. For instance, in the U.S.A., people like to possess the latest models of cars and discarding the old ones which are still in useable conditions. This leads to wastage of national resources.

\section{Effects of Marketing and Publicity on the Nigerian Theatre}

An effective and efficient marketing and publicity create an image for the theatre. According to the oxford reference Dictionary [Joyce M. Hawkin [ed], 1986:P174] effective means having the power to bring about the result that is intended or desired while publicity means an unpaid mass communication, the aim of which is to sell goods, service or ideas. Strictly speaking publicity is a form of communication, what differentiate it from advertising is that is not paid for.

To create the right image that will enhance the acceptability of the theatre through selling messages, the handler, who is a manager, must be sensitive to his environment. A clearly defined and targeted publicity gives confidence to the consumers and assures them of the utility of the product and enticed them to buy. It also gives a brand-new personality or image to the theatre and having developed the personality; publicity also helps in maintaining it. For instance, $80 \%$ of Newspaper readers read headlines so publicity employed this strategy to get at least $80 \%$ of the populace. By being simple, catchy and inviting in using headlines to publicise productions. If headlines are not used, $80 \%$ of the readers will miss the publicity which means losing $80 \%$ of the audience. In Radio commercials it must be unique otherwise it will not be needed and it must present one selling idea at a time .

Publicity must be credible, sincere, morally, legally and culturally acceptable and consumer oriented. Say what the audience want to hear and not what the director wants to say. The theatre cannot be complete without the audience who is the consumer. The audience cannot be aware of production without marketing/publicity and advertisement of such production. So, a well-planned and defined marketing strategies will attract audience to the theatre. The larger the audience will determine the profit that will be made by the theatre company. Apart from the issue of breaking even, the audience attendance psychologically affected both the performer as well as the performance. For example, the absence of small audience in a theatre hall, affects the artists performance arid, dampens their spirit in a life situation, whereas if the house is full, the artiste be gear up. Audience reactions during performances affect artistes psychologically and enhance their ability to put up the best. The theatre company as a business venture is audience conscious because without the audience there cannot be a theatre. So, for the audience to be thoroughly assured the publicity and marketing must be apt and well designed to attract audience. Publicity and marketing create an audience-performer relationship. The success of any commercial theatre performance is determined by the level of partnership and mutual, trust between the audience and the performer. Only marketing/publicity brings this kind of relationship because it indirectly prepares the audience for theatre going. It is the link between the theatre and the audience.

Publicity enhances public relations the relationship between an individual, company or group and the general public. It can, therefore, be described as a planned and sustained effort to establish and maintain mutual understanding of organisation and the public. Its purpose in the theatre is to establish a mutual understanding based on truth, knowledge and full information and enhance relationship by encouraging the attitude and behaviour which will nurture understanding. It also increases the realisation of the needs of communication and explain to the management what the public is thinking and explain to the public what the industry is doing.

In business, public relation promoted successful trading and a high level of profitability. If a company is to operate successfully it must be respected and accepted by consumers. It takes more than producing quality product to sell goods and services. Publicity, advertising and price tags are also interesting factors in making sales. Building up of goodwill is an essential part of commercial and industrial operations. The theatre can also be affected negatively, timing is important 
in sales promotion, if production is wrongly timed it will affect the audience attendance, thereby affecting the gate takings. If this continues for long time the audience will lose interest in the theatre.

Lack of well-defined and aggressive publicity and proper marketing strategies will lead to the death of the theatre. For instance, presently in Nigeria an average person is not theatre conscious. The theatre is more or less dead, only vigorous publicity can revive the theatre in Nigeria. Unless marketing strategies and publicity are given free hands to operate and placed first in the priority list by the administrator the theatre will not grow commercially as an industry.

\section{Effects of Publicity and Marketing on the Nigerian Economy}

Our progress as a country does not depend solely on the number of so-called enlightened politicians, but on the development of as many aspects of our national life as possible. We must advance in all facets of life in polities, education, art etc. If we are to prevent a lopsided development.

The wealth of a nation is measured by the economist in terms of the Gross National Product [GNP]-the value of goods and services produced during a particular accounting year on a time-series spectrum. The contribution of the theatre to the GNP is not only significant in assisting to provide solutions to societal problems, but its preservation of traditional and cultural values. Theatre is one of the most reliable sources of preserving cultural antiquity and creating cultural awareness from generation to generation. Historical performances show the country's, history and belief system. The Festival for Art and Culture [FESTAC'77] was an example of how the theatre can contribute to the economy of a nation. It gave international investors the opportunity to come into the country to exploit new grounds. A lot of art works were explored after the festival-admire, carvings, sculptures, art works etc had international recognition and acceptance. A lot of costumes and accessories used for performance attract investors who are ready to invest into such business. This gave local industries the opportunity of having international market and consumers And enhance the production of quality product that can equalize the international standard. Apart from the fact that individual actors gain international recognition, theatre companies also enjoy international recognition based on its performance in the festival. Transporters and food sellers were highly patronised. This is an avenue for a country to redeem her image in the eyes of the international community.

The theatre through its productions stands as the country's public relations in the eyes of the international community Edward Bernays in his book The Engineering of consent defines Public Relation as the "attempt by information, persuasion and adjustment to engineer policy support for an activity, course, movement or institution [Foreman Training Management in Nigeria: 1966 Vol.2 PP.8-11], Its purpose in the theatre is to establish a two way flow of mutual understanding that will encourage strong and healthy growth. The way the theatre practitioners comport themselves during performances in the eyes of the international community effected the country they are from, Even the type of performance common in a country has a subtle way of showing certain vices or virtues prevailing in such a country. The theatre mirrows the society and serve as a standard for measuring the country's level of discipline, poverty and development.

In Nigeria, we express a lot of concern about flamboyant living, general indiscipline and the lack of sense of dedication. Advertising, theatre and publicity can help the nation to build a better attitude to work and correct a general deal, of ills of the society. We need performances, and service-men-oriented publicity. That will emphasised the dignity of labour or service. It should be handled by first- class advertising agencies and media practitioners, also performances that will show the ills of the society and its consequences; should be employed. Government should utilize these avenues for the proper promotion of its ideas, beliefs, policies and principles. In foreign countries the government not only plans, prepares and places advertisement but also sponsors productions by funding.

The effectiveness of marketing is a function of its ability to address itself to the nation's diversified nature, so to be successful as a marketer we must address our minds and consciously see ourselves guided by our environmental nature. The act of marketing products; productively and effectively is perhaps the most challenging task in the competitive society of today.

Business environment has changed due to the increase in competition; innovations and diversification. One can say that no sector of the Nigerian economy has not faced competition, at one time or the other from the attainment of independence to date, and the theatre is no exception. Development in the business sector influence the environment and the behaviour of theatre practitioners. Not that other factors of production are not important and deserve attention, but the role of marketing and publicity in getting the finished product at the doorsteps of the consumers deserves more attention.; without which, the labour of other arms of production is in vain,

The method and manner in which a marketer market his product in this diversified. society differs in ethics, religious, political and social beliefs. These determine the types of publicity strategies to employed. The ability to relate with and understand the environment he operates in will influence iris success or failure. Our failure as marketers can be associated with our inability to appreciate the diversified nature of our society. The society is so complex that each of the over two hundred and fifty ethnic groups must be communicated to in a language they can decode. The employment of foreign way of advertisement/publicity will not enhance effective marketing in Nigeria. It does not appreciate our moral values/standard and the complexities of our cultural belief. Publicity if properly utilised will revive and revolutionise the nation. 


\section{Recommendations: Adopting an effective Marketing Mix for The Nigerian Theatre}

In recent years, it has been increasingly obvious that there is a need to make a fundamental change in the way theatre business is run. Low productivity, loss of audience to home video industry, declining profits, recessionary pressure combined, have put a lot of strain on every theatre practitioner only a few people will dispute that something of substance needs to be done in order to revive the declining enterprise.

The Traditional Total Quality Management [TQM] which is normally used by business executives to put forward the concept to the inverted management pyramid should be done away with. This old business is styled in the form of a pyramid with the producer at the top while other executives are underneath. There are many layers in the management structure which shows who report to whom. But the audience is not given a place in the structure. With this type of management structure, especially in today ${ }^{1}$ sreessed market the theatre business has no hope of getting anywhere. Business-audience- consciousness will not be there and the publicity/marketing managers are side tracked during vital decision making process or in case where they are allowed to be present they are forced to accept the management decisions while their own creative ideas, opinions and observations are neglected.

This has led to a lot of discomfort in the marketing of theatre product. It appears that because of ignorance the theatre business has been fundamentally mismanaged. The remedy suggested is that, since the audience is the most important person in the business, they should not be kept out of the chart, so they must be included in the communication structure. This will not only give the audience the most important role in driving the business, it will create a kind of audience awareness/consciousness in the management cadre and influence most of their decisions. It will remind them always that whatever decision taken will affect the audience positively or negatively thereby affecting gate takings. It will also give the frontline marketers a similar ability to relate freely with the audience since they are the closest to them. This appears to be a reasonable and long overdue proposition because it is not only going to improve relationship with the audience, but also improve the business itself. And the flow of communication from the audience and within the enterprise will vastly improve.

Once this idea is accepted the wills of management will change from a commanding role to a supportive role. According to this concept every employee in the company will support the marketing and publicity manager in the dissemination of information or performances of their duties. Though the whole concept sounds logical, the director/producer may oppose it because of the fear of losing power and their comfortable position with the organisation.

The fundamental reasons for failure and the inability to properly serve the audience is because of confusion between the hierarchy of authority and lack of communication flow within the enterprise. Theatre is a collaborative art. To achieve this everybody must work hand in hand, the communication structure must be totally flat so that anybody within the organisation can communicate with anyone else - communication in business has little to do with the hierarchy of authority if the communication is allowed to flow only along the lines of authority the business is doomed.

The audience, who did not enter the authority structure, certainly enters the communication line, marketing cannot function effectively and efficiently without lines of communication extending to the audience. So, board of directors, producers and artistic directors should create an atmosphere whereby publicity managers will be free to discuss issues and express themselves freely without fear of victimisation. A company has the chances of growth if there is an effective organisation of a communication system. However, failure to listen to suggestions no matter how silly or stupid they lead to frustration and lack of commitment.

\section{The laissez faire model}

The Laissez faire model was an economic policy developed by a classical philosopher and economist Adam smith. A method of commercialisation of colonies to economically sustain their colonial masters. Thus, it was propounded to liberate the consumers from a capitalist economy in which the National wealth, economy and the market power was vested in the covers of the bourgeoises. Advocated for a deviation from classical capitalism; which was to serve and liberate the common man from an astute State dominated economy. Which had politically and systematically increased structural unemployment, crime inequality, apathy and widen the gap between the rich and the poor thereby reduced the general standard of living. These were achieved through the salient National political and economic policies that were inimical to the common good. Smith advocated for an analytical analysis of democratic capitalism to determined how it has affected the ordinary citizen.

\section{INDICATORS OF A DEPRESSED ECONOMY}

A steady economic commotion for a period of time as a result of the fall in the rate of the Gross Domestic Product of a nation leads to economic depression.

A depressed economy is primarily caused by worsening consumer confidence that leads to a decrease in demand, eventually resulting in companies going out of business. When consumers stop buying products and paying for services, companies need to make budget cuts, including employing fewer workers. Other factors that lead to economic depression include:

\section{Stock market crash}

The stock market is composed of stocks that investors own in public companies. Changes in shareholdings can reflect how an economy is doing. When the stock market crashes, it can be an indication of investors' declining confidence in the economy. 


\section{Decrease in manufacturing orders}

A business flourishes on the demand for its products and services. When manufacturing orders reflect a decline, especially for an extended period, it can lead to a recession and worse, to an economic depression. 3. Control of prices and wages Price controls happened when prices kept going higher. Also, when wages are controlled by the government and companies are not allowed to lower them, businesses may be forced to lay off employees to survive.

\section{Deflation}

Deflation is basically the lowering of consumer prices over time. It may seem like a good thing because people can now afford to buy more commodities but underneath it is the fact that prices are lowered because of a decline in demand, too.

\section{Oil price hikes}

How oil price hikes can cause a ripple effect on almost everything in the market is common knowledge.

When it happens, consumers lose their purchasing power, which can lead to a decline in demand.

\section{Loss of consumer confidence}

When consumers are no longer confident in the economy, they will alter their spending habits and eventually reduce the demand for goods and services.

\section{Signs of an upcoming economic depression}

Before an economic depression happens, there are things that people should take notice of in order to be able to prepare for one. They include the following:

\section{Worsening unemployment rate}

A worsening unemployment rate is usually a common sign of an impending economic depression. With high jobless numbers, consumers will lose their purchasing power and eventually lower demand.

\section{Rising inflation}

Inflation can be a good sign that demand is higher due to wage growth and a sturdy workforce. However, too much inflation will discourage people from spending, and it can result in a lowered demand for products and services.

\section{Declining property sales}

In an ideal economic situation, consumer spending is usually high, including the sale of homes. But when there is an impending economic depression, the sale of homes goes down, signaling falling confidence in the economy.

\section{Increasing credit card debt defaults}

When credit card usage is high, it is usually a sign that people are spending, which is good for the GDP. However, when debt defaults rise, it could mean that people are losing their ability to pay, which signals an economic depression.

\section{Methodology}

Data were collected and analysed using the qualitative research method. Five publicity and marketing arms from five commercial theatres were interviewed. Thus gave an indept knowledge of how commercial theatres are run, the challenges they faced and the coping methods employed in a depressed economy. The focus group interviewed were the publicity and advertising managers, the theatre managers and the artistic directors. These were the direct practitioners and were conversant with the happenings within the sphere of the marketing profession.

\section{Interview}

A verbal interview was conducted among the five commercial theatres selected for the research work. The research population was five (5) artistic directors, five (5) publicity and advertisement directors, five (5) Theatre managers, and five (5) management teams which is one each from the different theatre companies. Thus, totally twenty (20) persons from five commercial theatres companies.

\section{Presentation and analysis}

An unstructured verbal interview was carried out among the 20 persons which covers 5 commercials theatres. The research questions cover the demographic knowledge of the respondents, in-depth knowledge of publicity and marketing. It also includes modes and methods of advertisement and how often the commercial theatre carry out advertisement, including the effect of the economy on the marketing strength of the commercial theatres. Descriptive data analysis method was employed to analyse the data collected. The selected respondents have been with their different theatre companies for a period of five to ten years respectively. The company's directors and theatre managers are all males. These companies have been established between 5-10 years with most of them still retaining their founding members

Respondents had a comprehensive knowledge of the importance of advertisement and publicity to the growth of theatre companies. These companies employed various means of advertising their performances such as Radio, native advertising, posters, billboards, flyers, social media, print advertisement, and outdoor advertising etc. It was gathered that the selected theatre companies advertise using the early mentioned methods but not in all productions because of the high cost involved. It was equally gathered that the economic depression has affected the patronage of theatre productions thus reduced their income generation. 
Most of these commercial theatres has reduced the numbers of productions per months and per week because of lack of patronage. Furthermore, other means of advertising could not be employed due to low sponsorship. Although these theatre companies are still in the theatre business, but it is on low scale, thereby devising other methods of keeping the theatre going.

\section{Conclusion and Recommendation}

It was discovered that because of the advancement in technology, theatre companies can no longer depend solely on the traditional methods of advertising which can only serve fewer people from the neighbourhood. This emphasizes the use of advertising to reach a large population, thus attracting more patronage. Many types of advertisement were neglected or under used such as Newspapers, magazine, Radio, Television, Direct mail, catalogues, directories. Because of lack of funds, these would have influence consumers and convert consumers into customers Due to lack of funds and financial producers, theatre companies solicit for publicity which is an unpaid means of advertising production from media houses. Also, the negative effect of the economic depression is visible not only in the companies but also with the actors, actresses and cast of the respective theatre companies.

The research therefore suggested that the theatre companies should diversity. Establish/create a parallel company that will serve as a servicing companies to theatre companies without losing focus of the purpose of the theatre. Such companies as the costume/make up stores, dance and music therapy, props, designing and lightening outfit. These will not only attract customers who will end up being theatre patronage but enhance the generation of income for advertising purpose and the expansion of the theatre.

\section{References Books}

[1].Akomolafe, Olu: Theatre management in Nigeria appraisal and challenges in Qqunbiyi Nigerian Magazine, Lagos, 1981.

[2].Bashr, Lauren S. et al [ed]: Colliers Encyclopedia Collier incorporation, Danbury, 1992.

[3].Berkman, Harold N. et al: Advertising concepts and strategies Random House, New York, 1980.

[4].Brarrt, Leon L [ed] : Funk and Wagnals new Encyclopedia funk and wagndls, USA, 1996.

[5].Brockett, Oscar G. : Theare History sixth edition Boston, Allyn and Bacon, 1968 Theatre and Introduction Holt, Rinehart and Winstion Inc., New York, 1974.

[6].Chamber, E.K.: The Elizabethan State Oxford University Press, vol.1, 1923.

[7].Clark, Ebun: Huberbert Ogunde: The making of the Nigerian Theatre England Oxford press, Oxford 1980.

[8].Clifford, John E,: Educational Theatre Management Skokie,National textbooks Co., 1972.

[9].Colson-Thomas, Colin J.: Marketing Communications, Heinernann, London, 1986.

[10]. Giles, G.B.: Marketing Macdonald and Evans Ltd, US, 1978.

[11]. Hawkin, Joyce M [ed]: The Oxford Reference Dictionary Clavendon press, Oxford, 1986.

[12]. Jeyifo, Biodun: The Yoruba popular travelling theatre of Nigeria Nigeria magazine, Lagos, 1984.

[13]. Kafman, Louis: Essential, of Advertising Harcourt Brace Joranovish Inc., Toronto, 1980.

[14]. Langley, Stephen: Theatre management in America: Principle and practice, Drama book publishers, New York, 1980.

[15]. Ogunbiyi, Yemi [ e d ] : Drama and theatre in Nigeria: A Critical Source Book, Nigeria magazine, Lagos, 1981 Perspectives on Nigerian literature 1700 to the present. Guardian books Ltd, vol.1 1988.

[16]. Stanley, Richard E. Promotion, advertising, publicity, personal selling, sales promotion^, prentice hall Jersey Inc., Englewood Cliffs, New Jersey, 1977.

[17]. The Encyclopedia Americana-International Grolier incorporated, Danbury, 1972.

[18]. William Baumol et al: Performing arts: The economic dilemma: A study of problems common to the theatre, opera, music and dance, connecticute printers, USA 1966.

\section{Journals}

Adedeji J.A.: "The chruch and the emergence of the Theatre 1866-1914" in the Journal of the Historical Society of Nigeria, Damba Osomba: "The roles of theatre in a developing society: the Nigerian example" in Nigeria magazine vol.54 Nos.3 1986.

Doghudje Chris: "Advertising as a nation Builder" in management in Nigeria journal of Nigerian Institute of Management vol.14, No.6 July 1978.

Gorecki Andrzej Tomasz "The fatal attraction of the inverted Management Pyramid". In Management in Nigeria Journal of institute of management vol.32, Nos.3 and 4, July- December 1996.

Osaze B. E: "Organisational effectiveness in industry" In management in Nigeria journal of Nigerian institute of management vol.22. Nos,3 and 4 March/April, 1986. 